\title{
Induction of the Xenopus organizer: expression and regulation of Xnot, a novel FGF and activin-regulated homeo box gene
}

\author{
George von Dassow, ${ }^{1}$ Jennifer E. Schmidt, ${ }^{1}$ and David Kimelman ${ }^{1,2}$ \\ Department of Biochemistry SJ-70, University of Washington, Seattle, Washington 98195 USA
}

\begin{abstract}
We have searched for homeo box-containing genes expressed during gastrulation in Xenopus embryos with the expectation that analysis of the spatial and temporal expression of these genes will lead to greater understanding of the regionalization of the mesoderm. We describe the cloning and expression of Xnot, a novel homeo box-containing gene expressed primarily in the gastrula organizing region. We have studied the regulation of $X$ not by signaling molecules involved in mesoderm induction and regionalization. Surprisingly, we found that FGF signaling is required for expression of Xnot in the gastrula organizing region, clearly implicating FGF in the induction of dorsal mesoderm. Furthermore, we found that Xnot is initially expressed throughout the embryo and that progressive translation of an unknown protein restricts expression of Xnot to the organizing region. Our results provide experimental evidence supporting the proposed division of Spemann's organizer into independently regulated organizing centers.
\end{abstract}

[Key Words: Mesoderm induction; fibroblast growth factor; homeo box genes; Spemann's organizer]

Received November 24, 1992; revised version accepted January 6, 1993.

Although the small region of cells located above the dorsal lip of the gastrulating Xenopus embryo has generated considerable enthusiasm since it was discovered and named the "organizer" by Spemann and Mangold (1924), little is known about the regulation or molecular composition of this region. Although Spemann's organizer region was originally conceived of as a single entity that regulates the formation of the body axes during gastrulation (Spemann 1938), it has been proposed recently that this region of the embryo is the site of several organizing centers that are expressed in a temporal sequence (Gerhart et al. 1991). The earliest of these organizers, the Nieuwkoop center, is established during the early cleavage stages in the dorsal vegetal hemisphere and is responsible for establishing Spemann's organizer region in the dorsal-most part of the equator. Experimental evidence suggests that the gastrula stage region identified by Spemann may be composed of at least two organizing centers: one that initiates gastrulation and contributes to the cells that will form the head, and a later center that forms the axis of the body and is composed primarily of cells that will form notochord (Kaneda and Hama 1979; Gerhart et al. 1991). The two organizing centers that are active during gastrulation will be referred to here as the head organizer and the body axis organizer. Because the

\footnotetext{
${ }^{1}$ All three authors contributed equally to the experiments presented here. ${ }^{2}$ Corresponding author.
}

term Spemann's organizer implies that the dorsal equatorial region contains only a single organizing center, we have instead referred to this group of cells as the gastrula organizing region.

Two recent approaches have been used to find molecules involved in the induction of the gastrula organizing region. One approach has been to identify intercellular signaling molecules that may be involved in the induction of this region of the embryo. Factors such as fibroblast growth factor (FGF) (Kimelman and Kirschner 1987; Slack and Isaacs 1989) and activin (Smith 1987; Smith et al. 1990; Thomsen et al. 1990) can directly induce mesoderm. Xwnt-8 (Christian et al. 1991, 1992; Smith and Harland 1991) and noggin (Smith and Harland 1992) do not directly induce mesoderm but can restore a complete body axis in an embryo ventralized by UV irradiation (Smith and Harland 1991; Sokol et al. 1991; Smith and Harland 1992), possibly by changing the competence of ectoderm to respond to mesoderm inducing factors (Spemann 1938; Christian et al. 1992; for review, see Kimelman et al. 1992). Of these factors, noggin has been shown to be produced specifically within the gastrula organizing region (Smith and Harland 1992) whereas FGF is present in the marginal zone (Shiurba et al. 1991; T.J. Schuh, S.D. Hauschka, and D. Kimelman, in prep.) and vegetal hemisphere (Shiurba et al. 1991). The distribution of activin in the early embryo has not been reported. Because Xwnt-8 is not expressed mater- 
nally, it is unlikely to be involved in organizer induction. Instead, ectopic expression of Xwnt-8 may mimic another signal, possibly a maternally expressed $X w n t$ family member (Christian et al. 1991; Smith and Harland 1991; Sokol et al. 1991).

A second approach to the gastrula organizer has been the identification of genes encoding transcription factors that are likely to have a role in the formation of the gastrula organizing region. The first of these to be identified was the gene goosecoid, which is transcribed solely within the gastrula organizing region (Cho et al. 1991). Injection of RNA encoding goosecoid into the ventral side of an embryo produces a secondary axis, with varying frequency and completeness. Since the intercellular signaling factors Xwnt-8 (Smith and Harland 1991; Sokol et al. 1991)and noggin (Smith and Harland 1992) are much more effective at inducing a complete axis than goosecoid (Cho et al. 1991), it is likely that the embryo requires the expression of multiple transcription factors within the organizer region to initate events leading to the development of a complete axis. Supporting this possibility, transcripts from genes encoding three other likely transcription factors have also been found within this region: Xlim, which is also transcribed specifically within the gastrula organizing region (Taira et al. 1992), and two Xenopus fork head genes (XFKH1, Dirksen and Jamrich 1992; Pintallavis, Ruiz i Altaba and Jessell 19921, which are transcribed within the dorsal quadrant of the equatorial region. All four of these genes are inducible by activin but not by FGF in animal cap explants (Cho et al. 1991; Dirksen and Jamrich 1992; Ruiz i Altaba and Jessell 1992; Taira et al. 1992).

We have identified a novel homeo box-containing gene, which we have named Xnot for Xenopus notochord-specific, that is expressed within the organizing region of a gastrula-stage embryo. Analysis of the temporal and spatial expression of this gene suggests that it performs a different function than the genes described above and may represent a component of the body axis organizer proposed by Gerhart (1991). We have studied the regulation of this gene to further understand the induction of the gastrula organizing region and find that it can be regulated by several different factors, including FGF, activin, and DVR-4. The ability of FGF to induce the transcription of Xnot, and the elimination of Xnot expression by a dominant-negative mutant of the FGF receptor, provides strong support for the contention that FGF is directly involved in the induction of dorsal mesoderm. We propose a model in which Xnot is regulated by a series of inductive events that limit the expression of this gene to the body axis organizer.

\section{Results}

\section{Isolation and sequence of the Xnot gene}

The Xnot gene was first identified in a search for homeo box-containing genes transcribed during the gastrula stages. A collection of polymerase chain reaction (PCR) fragments containing a part of the homeo box sequence was synthesized from gastrula-stage RNA using degenerate oligonucleotide primers to conserved regions of the homeo domain, and the DNA sequence of each fragment was determined. Several unique genes were identified, including one that has since been named Xnot. Preliminary analysis indicated that Xnot was expressed during the gastrula and neurula stages; therefore a Xenopus neurula-stage cDNA library was screened (Kintner and Melton 1987). The longest cDNA identified was $2.0 \mathrm{~kb}$, which is close to the predicted size of the Xnot transcript (see below). However, the terminal $3^{\prime}$ end of the transcript appears to be missing, as there was no evidence of a poly $(\mathrm{A})$ tail at the end of the cDNA.

The DNA sequence of the longest Xnot cDNA contains one long open reading frame that includes the homeo box sequence and encodes a protein of 236 amino acids (predicted molecular mass of $27.4 \mathrm{kD}$; Fig. 1A). An untranslated region of 480 nucleotides precedes the putative initiation codon (Fig. 1C). Analysis of this region by RNase protection demonstrated that it was part of the $X n o t$ transcript and was not an artifact of the cloning process (data not shown). The putative Xnot protein can be subdivided into three parts: an amino-terminal region, the homeo box, and a carboxy-terminal region (Fig. 1C). Neither of the terminal regions has significant homology to other known proteins. The carboxy-terminal end of the predicted protein is rich in acidic residues and is predicted to form an $\alpha$-helix. Most of the acidic residues lie on one face of the predicted $\alpha$-helix, as is found in other transcriptional-activating proteins (Ptashne 1988). The presence of this domain suggests that the $X n o t$ protein may have a trans-activating function. The sequence of the Xnot homeo box is quite divergent from other known homeo box genes. The closest relative is the Drosophila empty spiracles (Fig. 1B, 61.7\% identity). A lesser extent of sequence conservation was found to other members of the msh family of homeo box proteins such as E5 and Hox-7 as well as to the Drosophila evenskipped (eve), rhomboid (ro), and Antennapedia (Antp) genes (Fig. 1B). Xnot is unlikely to be the Xenopus homolog of ems, as two murine ems homologs are $81 \%$ identical to ems within the homeo box. Xnot is also unlikely to be a member of the msh family, which includes ems, as it is no more similar to msh family member Hox-7 than to non-msh homeo box genes such as eve and ro. We conclude that Xnot represents a novel class of homeo box gene.

\section{Temporal expression of the Xnot gene during early development}

The levels of transcripts from the Xnot gene during early development of the Xenopus embryo are shown in Figure 2. An $\sim 1.8-\mathrm{kb}$ maternal transcript was found in the unfertilized egg (Fig. 2, lane 1), suggesting that Xnot may have a role during oogenesis or early embryogenesis, although we have noticed variable levels of this transcript in unfertilized eggs from different frogs (e.g., Fig. 3, lane 1). A slightly larger transcript of $\sim 2$-kb was transcribed before the onset of gastrulation (Fig. 2, lane 2). By the end 


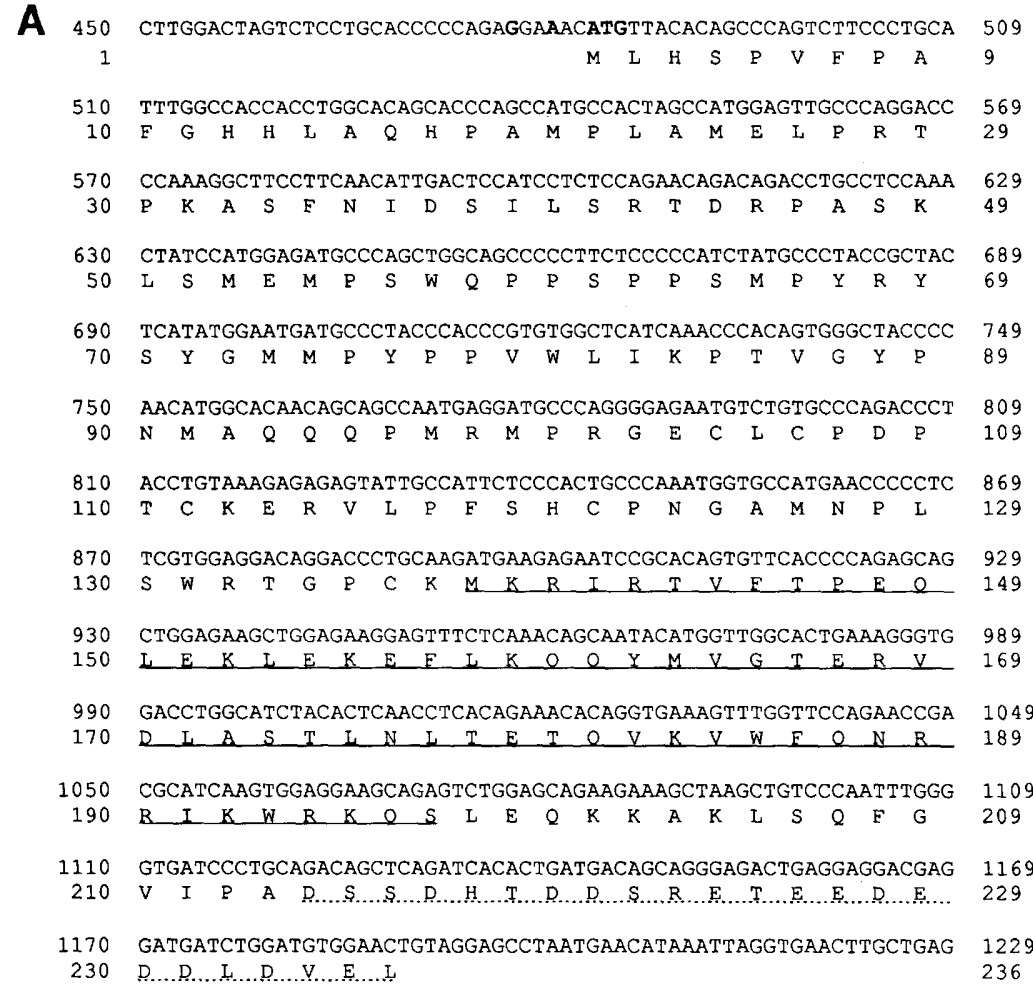

B

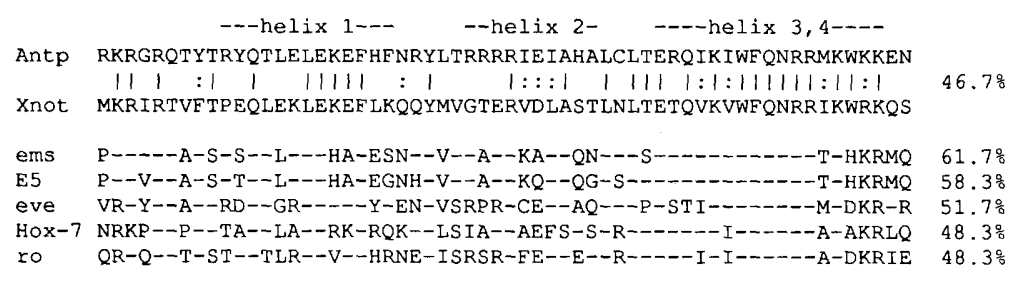

C

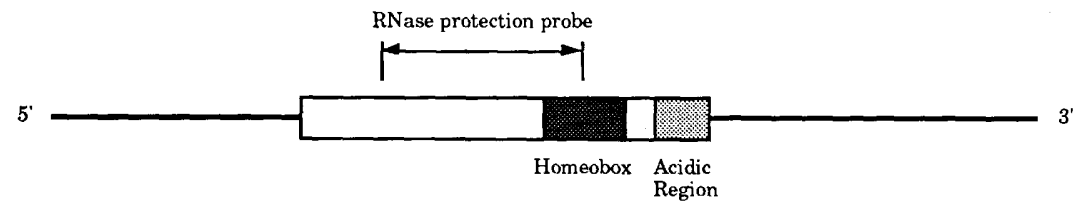

Figure 1. $(A)$ The nucleotide sequence of $X n o t$ and its predicted amino acid sequence. The homeo box sequence is indicated by a solid underline, and the acidic region is indicated by a broken underline. The predicted initiation codon and $5^{\prime}$ nucleotides that match the consensus translational initiation sequence (Kozak 1987) are indicated in boldface type. $(B)$ Comparison of the Xnot homeo box sequence to other homeo box sequences (Laughon 1991). The four predicted helices within the homeo box region are indicated (Laughon 1991). (C) Schematic illustration of the Xnot clone, with the boxed region indicating the open reading frame. The positions of the homeo box and acidic regions are indicated. The portion of the cDNA used to produce an RNase protection probe is also shown. of gastrulation, the levels of Xnot have declined, although the Xnot transcript is retained into the late tailbud stages (Fig. 2; see also Fig. 4G). The smaller size of the maternal transcript relative to the zygotic transcript could be the result of differences in the length of the poly(A) tail or alternative splicing of the Xnot mRNA.

A more sensitive analysis of RNA transcript levels using RNase protection analysis demonstrated that Xnot transcripts began to accumulate markedly at the midblastula transition (MBT) (Fig 3A, lane 3). Because the frog used in this experiment had an undetectable level of the maternal transcript (Fig. 3A, lane 1), the transcript observed at $7 \mathrm{hr}$ must be the result of new transcription from the Xnot gene. The level of Xnot transcripts peaked at the onset of gastrulation (Fig. 3A, lane 6) and then declined rapidly during the gastrula stages (Fig. 3A, lane 7). Another decrease in Xnot levels occurred toward the end of the neurula stages (Fig. 3A, lane 9). Each of these changes correlated with a distinct change in the spatial distribution of Xnot transcription (see below). In summary, the temporal expression of Xnot is consistent with a role for this gene during the gastrula stages of development.

\section{Regional expression of the Xnot gene}

The localized expression of the Xnot gene was determined by RNase protection and whole-mount in situ hybridization (Harland 1991). The Xnot transcripts present at stage 9 (pregastrula) appeared not to be localized within the embryo as judged by in situ hybridization (data not shown). To measure the distribution of Xnot transcripts in a stage 9 embryo, the embryo was dissected into thirds and analyzed by RNase protection. By 


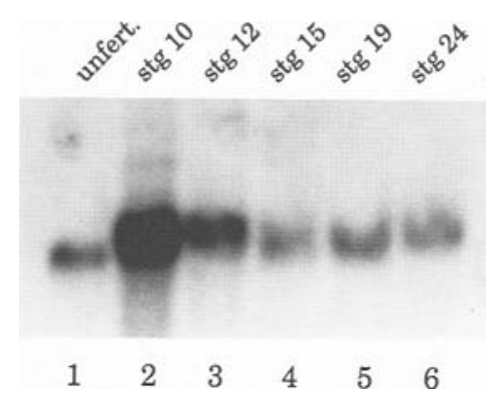

Figure 2. Developmental expression of Xnot. Poly $\mid A)^{+}$RNA was isolated from 50 unfertilized eggs and 50 embryos each at different stages, separated on a gel, blotted, and hybridized with a full-length probe made from the Xnot cDNA. (Lane 1) Unfertilized egg; (lane 2) stage 10 (early gastrula); (lane 3) stage 12 (late gastrula); (lane 4) stage 15 (neural plate stage); (lane 5) stage 19 (neural tube stage); (lane 6) stage 24 (tailbud). The blot was rehybridized with an EF1- $\alpha$ probe (Krieg et al. 1989) to verify the loading of RNA in each lane.

'comparison to the ubiquitously expressed gene-encoding elongation factor 1- $\alpha$ (Krieg et al. 1989), Xnot transcripts were found at this stage in the primordia for each of the three major germ layers at equivalent levels (Fig. 3B). By stage 10.5 (early gastrula), Xnot expression was restricted to the most dorsal mesoderm within the gastrula organizing region and to a narrow belt encircling the embryo (Fig. 4A,B). Because the cells expressing Xnot were not immediately adjacent to the blastopore lip in a stage 10.5 embryo (Fig. 4B), it appeared that Xnot was expressed within the prospective notochord region and not in the future head mesoderm, which has already involuted by this stage (Keller 1976). The equatorial belt of expression was quite distant from the blastopore at this stage (Fig. 4B) and may demarcate the limit of mesoderm involution (Keller 1976).

By the end of gastrulation, Xnot was expressed along the dorsal midline of the embryo (Fig. 4C,D). Whereas the anterior limit of staining was diffuse, the posterior staining terminated sharply at the blastopore (Fig. 4D). During neurulation, Xnot continued to be expressed along the dorsal midline, with expression clearly continuing into the anterior region (Fig. 4E). Transverse sec-

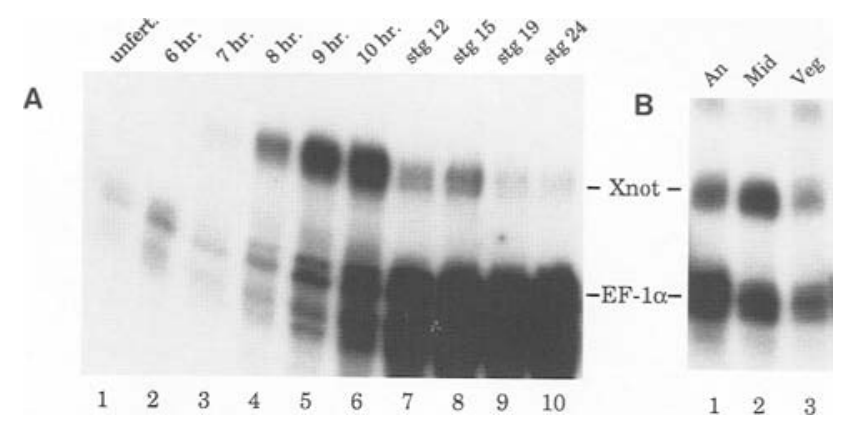

Figure 3. Analysis of Xnot expression by RNase protection. $|A|$ RNA was isolated from five unfertilized eggs and five embryos each at different stages of development. RNA was analyzed by RNase protection using a mixture of Xnot and EF1- $\alpha$ probes, with the $E F 1-\alpha$ probe at a reduced specific activity. Note that the MBT occurs at $7 \mathrm{hr}$ and that $10 \mathrm{hr}$ corresponds to a stage 10 (early gastrula) embryo. Stage 12 is late gastrula stage, stage 15 is neural plate stage, stage 19 is neural tube stage, and stage 24 is tailbud stage. $(B)$ Distribution of Xnot in a stage 9 (late blastula) embryo. Stage 9 embryos were dissected into animal (An), middle (Mid), and vegetal (Veg) thirds and analyzed as in $A$.

tions of embryos at stages 12.5 (Fig. 5A), 16 (Fig. 5B), and 18 (Fig. 5C) demonstrated that Xnot was transcribed within the notochord, archenteron roof, and in the overlying ectoderm that will become the floor plate of the neural tube. Similar expression patterns have been observed for the two Xenopus fork head homologs (Dirksen and Jamrich 1992; Ruiz i Altaba and Jessell 1992). Two new sites of Xnot expression appeared during the neurula stages on either side of the anterior neural folds (Fig. 4E). By the early tailbud stages, the expression of Xnot along the body axis was limited to the most posterior notochord and floor plate (Fig. 4F). In later stages, the expression was restricted to the extreme tip of the extending tail (Fig. 4G). The two anterior spots of expression along the neural folds converged during the neurula stages until they fused by the early tailbud stages in the region that will become the epiphysis, the precursor of the pineal body (Fig. 4F,G). Fainter staining was observed during the late tailbud stages in other regions of the brain (Fig. 4G).

Figure 4 Spatial distribution of Xnot transcripts during early development. Xnot expression was analyzed by the whole-mount in situ procedure using albino embryos. $|A|$ Vegetal view of stage 10.5 embryos. The dorsal lip is at the top. Note the intense staining just above the dorsal lip and the equatorial staining well above the blastopore lip (arrow). $(B)$ Close-up of stage 10.5 embryo. The sharply delimited staining of Xnot is apparent above the blastopore lip in the prenotochordal territory. The staining does not extend all the way to the lip (arrow) as with other organizer-specific genes (Cho et al. 1991; Dirksen and Jamrich 1992; Ruiz i Altaba and Jessell 1992; Taira et al. 1992). (C) Dorsal view of stage 12 embryos. The equatorial expression is no longer present. Xnot is found only along the dorsal midline in the region that will give rise to the notochord. Anterior is at the top. $(D)$ Close-up of a stage 12 embryo demonstrating the gradient of expression at the anterior end and the sharp termination of expression at the blastopore. Anterior is at the top. (E) Stage 16 embryo. Xnot expression extends from the anterior (top) to the posterior along the dorsal midline, with the strongest expression in the posterior. Two new spots of Xnot expression appear on either side of the neural plate. $(F)$ Stage 23 embryos. Xnot is expressed only in the posterior part of the notochord and floor plate along the body axis. In the anterior region, the two spots of Xnot expression have almost converged as the neural plate folds up. Anterior is at the top. (Left embryo) Dorsal is at left; (middle embryo) dorsal view; (right embryo) dorsal is at right. $(G)$ Stage 30 embryos. Only the most posterior tip of the body axis (the tailbud, t) contains Xnot transcripts. In the anterior region, the two spots of Xnot expression have converged in the epiphysis (e), the precursor of the pineal body. Faint expression in other regions of the brain is also apparent. 


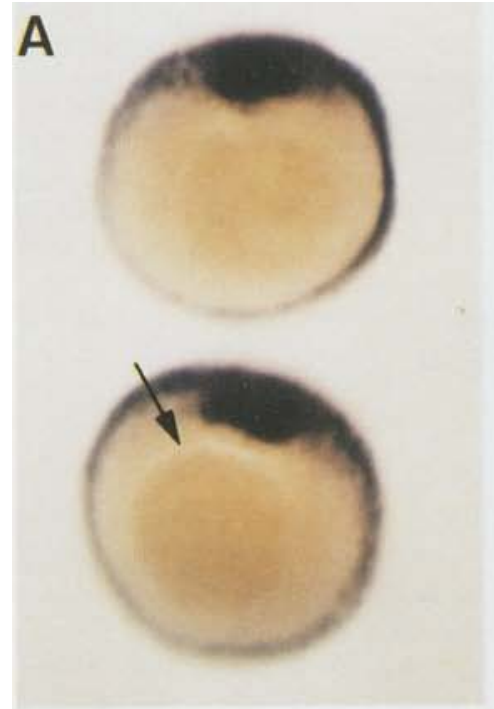

\section{B}
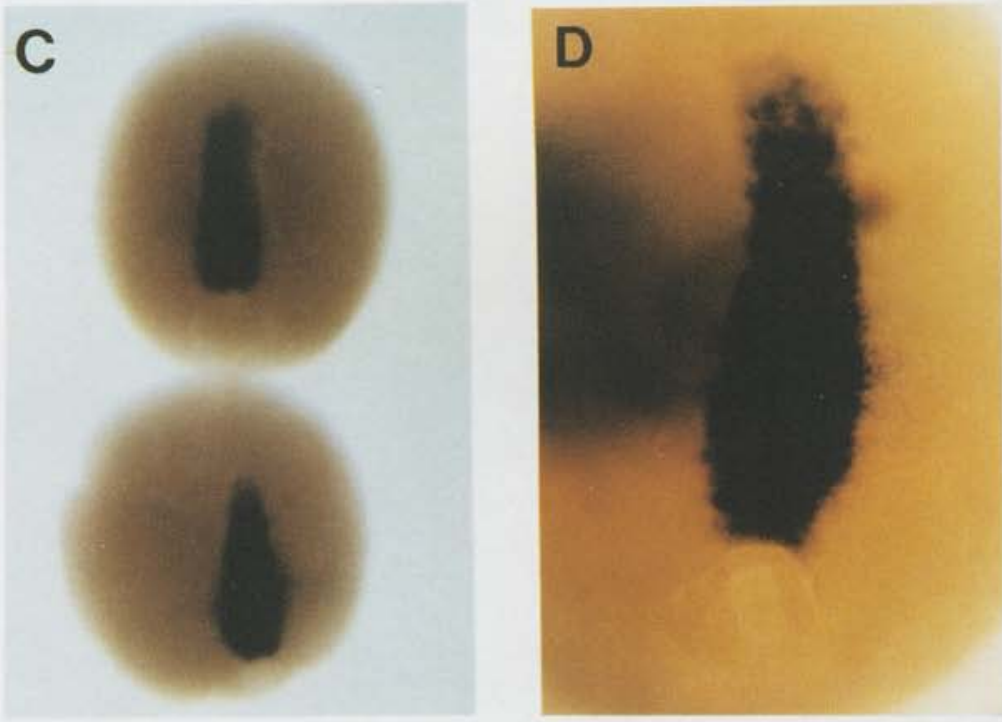

E

F

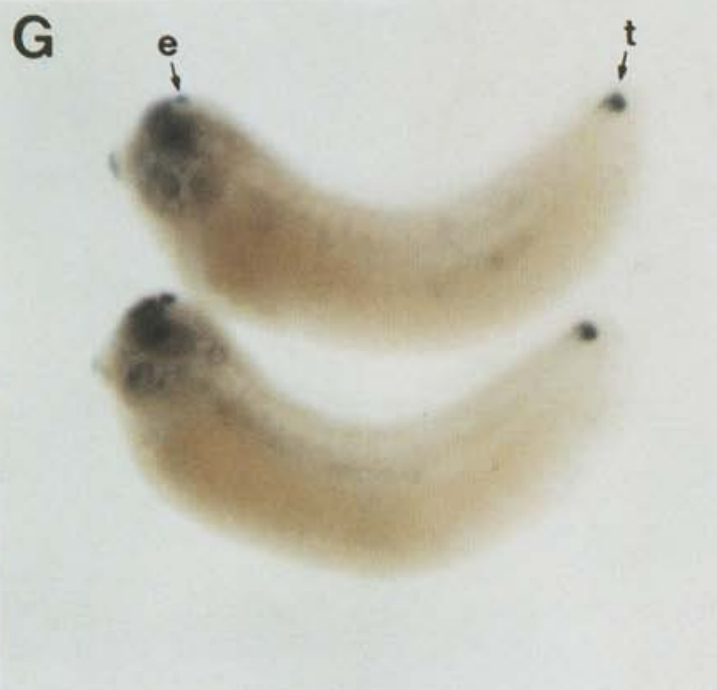

Figure 4. (See facing page for legend.) 

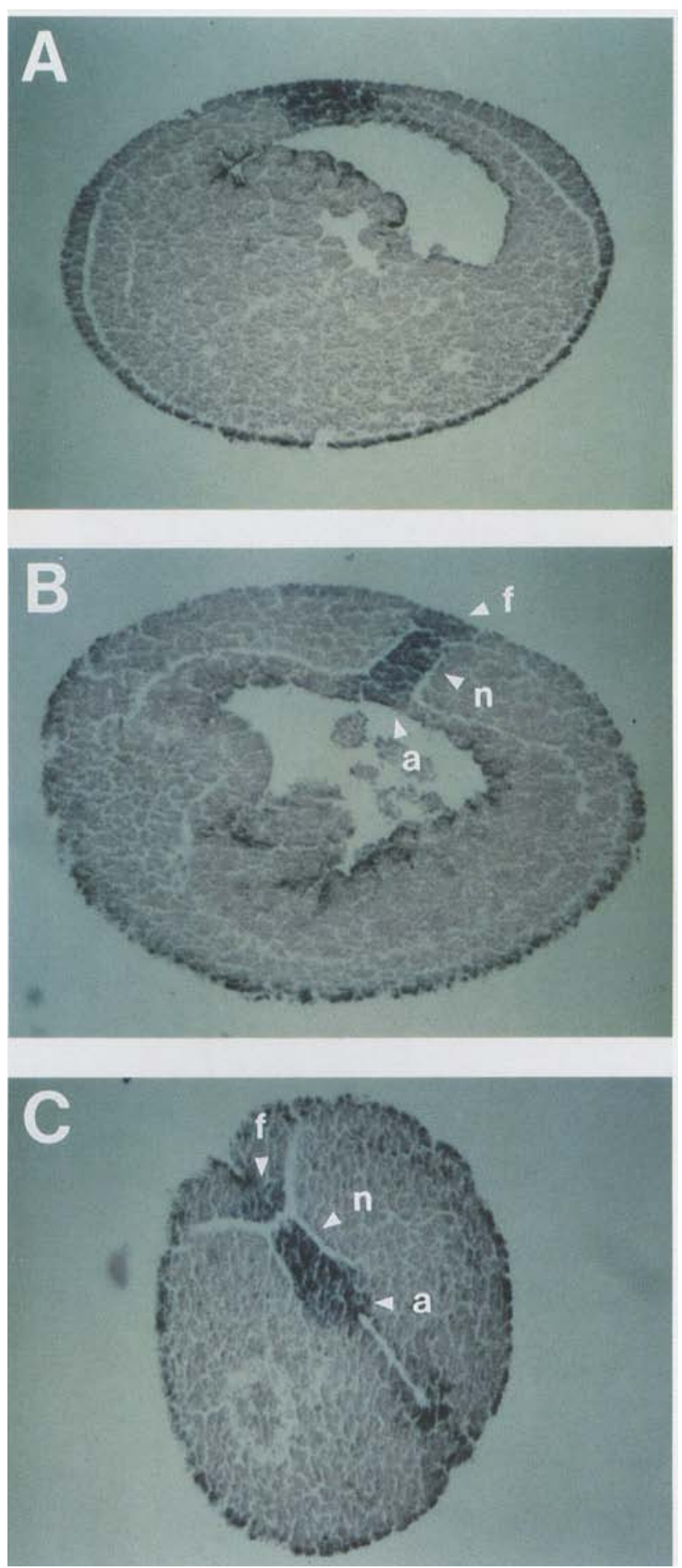

\section{Growth factor regulation of Xnot}

The localized expression of Xnot suggests that it is likely to be activated by specific inductive signals. goosecoid, Xlim, and the Xenopus fork head homologs are induced in animal cap explants by activin but not by FGF /Cho et al. 1991; Dirksen and Jamrich 1992; Ruiz i Altaba and
Figure 5. Expression of Xnot along the dorsal midline. Embryos were processed for whole-mount in situ hybridization and embedded in paraffin, and transverse sections were cut. $(A)$ Section through the middle of a stage 12.5 (late gastrula) embryo. Staining is observed only at the dorsal midline in all three germ layers. The archenteron was slightly deformed during sectioning. (B) Posterior section of a stage 16 (neural plate stage) embryo. Xnot expression is observed along the dorsal midline in the notochord $(\mathrm{n})$, archenteron roof $(\mathrm{a})$, and in the floor plate (f) of the neural tube. $(C)$ Posterior section of a stage 18 (neural fold stage) embryo. The same regions expressed Xnot as in $B$. Dorsal is at the top of each section.

Jessell 1992; Taira et al. 1992). As shown in Figure 6A, activin was able to induce Xnot expression in animal cap explants sixfold over the level found in untreated caps. Unlike these other genes, however, FGF was able to induce Xnot expression, albeit at a twofold lower level than activin (Fig. 6A, lane 2). Because Xnot transcripts were not detected in the animal hemisphere by in situ hybridization at this stage, the low level of Xnot expression in uninduced animal cap explants must be below the level of detection by in situ hybridization. To test whether Xnot required the translation of other proteins to be transcribed, the protein synthesis inhibitor cycloheximide was added together with activin when the animal caps were isolated at stage 8 and remained in the culture medium until the animal caps were harvested for RNA analysis at stage 12 . As with the other organizerspecific genes, cycloheximide did not block the expression of Xnot (Fig. 6A, lane 4). Surprisingly, a high level of

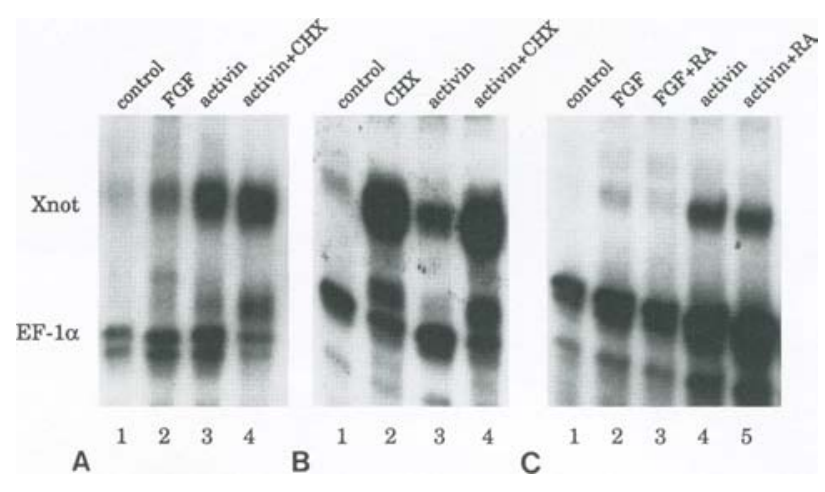

Figure 6. Activation of Xnot expression by mesoderm-inducing agents. Animal caps were removed at stage 8 and cultured with various treatments. RNA was isolated at the equivalent of stage 12 for RNase protection analysis using a mixture of Xnot and $E F 1-\alpha$ probes, with the $E F 1-\alpha$ probe at a reduced specific activity. (A) Both FGF and activin induce $X$ not expression. (Lane 1) No factors added; (lane 2) FGF added; (lane 3) activin added; (lane 4 ) activin and cycloheximide (CHX) added. (B) Addition of cycloheximide alters the levels of Xnot. (Lane 1) No factors added; (lane 2) cycloheximide added; (lane 3) activin added; (lane 4) activin and cycloheximide added. (C) Retinoic acid (RA) does not significantly affect the expression of Xnot. (Lane 1) No factors added; (lane 2) FGF added; (lane 3) FGF and retinoic acid added; (lane 4) activin added; (lane 5) activin and retinoic acid added. 
Xnot expression was observed when cycloheximide alone was added to animal cap explants (Fig. 6B, lane 2). In normal embryos, Xnot was expressed at a high level at stage 10, but the level of Xnot expression was greatly diminished by stage 12 (Fig. 3A, cf. lanes 6 and 7). We suggest that the addition of cycloheximide prevents the normal elimination of Xnot transcripts by preventing the translation of an unknown protein necessary for the repression or elimination of the Xnot transcripts.

As described above, the loss of Xnot transcripts from areas outside of the organizing region appeared to proceed in two steps: First, the nonequatorial transcripts disappeared, and then the equatorial transcripts outside of the organizing region vanished. To ask whether each of these steps could be altered by inhibiting protein synthesis, embryos were treated with cycloheximide at stage 9 and fixed when control embryos had reached stage 12. Each of 17 embryos treated in this manner maintained Xnot transcripts throughout the embryo (Fig. 7A), whereas untreated stage 12 embryos expressed Xnot only within the organizing region (Fig. $4 \mathrm{C}, \mathrm{D}$ ). The absence of staining in the deep vegetal region is an artifact of the procedure (Frank and Harland 1992). Cycloheximide treatment of embryos at stage 10 resulted in the retention of the equatorial band of Xnot transcripts at the equivalent of stage 12 in each of 11 embryos, but the nonequatorial expression was eliminated (Fig. 7B). In summary, treatment of embryos at stage 9 or 10 with cycloheximide prevented the elimination of Xnot transcripts from areas of the embryo outside of the organizing region. These results are consistent with a stepwise inhibition of Xnot transcription or the selective degradation of the Xnot transcript by a protein synthesized during stages 9 and 10 .
Retinoic acid has been strongly implicated as an important factor in the regulation of homeo box-containing genes. Retinoic acid can activate transcription of Xlim in animal cap explants and can potentiate the expression of Xlhbox 6, a homeo box-containing gene of the Hox class (Cho and De Robertis 1990; Taira et al. 1992). The activin-induced expression of goosecoid, in contrast, is greatly reduced by the addition of retinoic acid (Cho et al. 1991). Treatment of animal caps with retinoic acid alone did not activate the transcription of Xnot (data not shown). Addition of retinoic acid to animal caps treated with FGF (Fig. 6C, lanes 2,3) or activin (Fig. 6C, lanes 4,5) did not reproducibly enhance or repress the level of Xnot transcripts. In the experiment shown here, retinoic acid caused a slight decrease in the FGF-enhanced expression of Xnot (Fig. 6C, lanes 2,3); this result was not observed in subsequent experiments. We therefore conclude that Xnot can be regulated by either of the known mesoderminducing pathways, although in this assay FGF appeared to be less effective than activin. In addition, retinoic acid did not have a significant effect on the ability of either factor to enhance Xnot transcription.

\section{Regulation of Xnot expression within the embryo}

The animal cap experiments suggested that several factors may regulate the expression of Xnot. We have pursued these studies in vivo using RNA encoding two factors that regulate mesoderm induction and a dominantnegative mutant of the FGF receptor. The localized expression of Xnot within the organizing region raised the possibility that it might be regulated by $X w n t$ or noggin signals. Both of these factors can rescue embryos ventralized by UV irradiation (Smith and Harland 1991;

Figure 7. Xnot expression is altered by cycloheximide and injected $X w n t-8$, DVR4, and FGF dominant-negative receptor RNAs. Xnot expression was analyzed by the whole-mount in situ procedure using pigmented embryos. (A) Cycloheximide was added to stage 9 embryos that were then left to develop until control embryos reached stage 12 . Lateral view with the animal pole at top. The lack of staining in the vegetal region is an artifact of the whole-mount procedure. $(B)$ Cycloheximide was added to stage 10 embryos that were then left to develop until control embryos reached stage 12 . Vegetal view with dorsal side at top. $(C)$ Embryos were injected with Xwnt-8 RNA in one of the ventral vegetal cells of an 8- to 16-cell embryo. Embryos were fixed at stage 11. Vegetal view. Note the two sites of Xnot expression at the equator (arrows). (D) Embryos
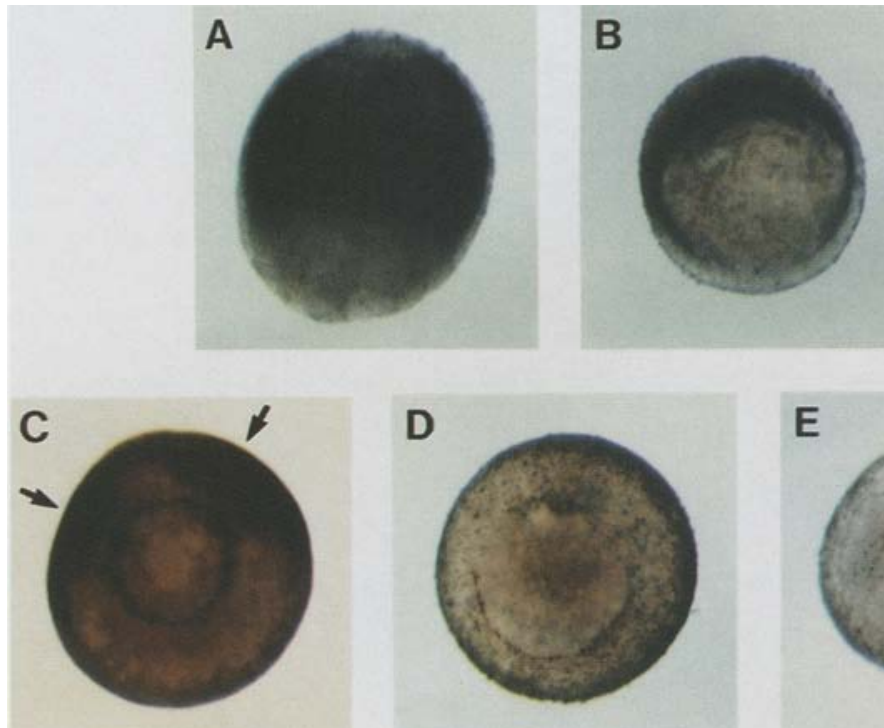

D

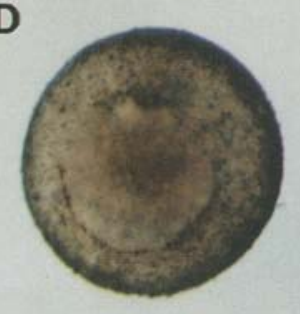

E

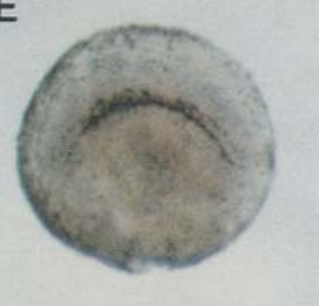
were injected with DVR-4 RNA at the equator in the two dorsal cells of four-cell embryos. Embryos were fixed at the equivalent of stage 11 . Vegetal view with dorsal side at top. Note the lack of Xnot expression. $(E)$ Embryos were injected with RNA encoding the dominant-negative mutant of the Xenopus FGF receptor in the two dorsal cells of four-cell embryos. Embryos were fixed at the equivalent of stage 12 . Vegetal view with dorsal side at top. No Xnot expression was detected. 
Sokol et al. 1991; Smith and Harland 1992). Injection of $X w n t-8$ RNA into one of the ventral vegetal cells of a 8to 16-cell embryo produced a second site of expression of $X$ not at the equator of a midgastrula embryo (Fig. 7C; Table 1), a result that is consistent with the proposition that the Xwnt-noggin pathway determines the site of the gastrula organizing region along the equator (Christian et al. 1992; for review, see Kimelman et al. 1992).

DVR-4 (bone morphogenetic protein-4) is a member of the transforming growth factor- $\beta$ family that is present in the unfertilized egg and is zygotically expressed at the MBT (Dale et al. 1992; Jones et al. 1992). Injection of RNA encoding DVR-4 into the embryo inhibits the formation of dorsal structures, although it does not disrupt the normal timing of gastrulation (Dale et al. 1992; Jones et al. 1992). To test whether DVR-4 can interfere with the expression of an organizer-specific gene, DVR-4 RNA was injected into the two dorsal cells of a four-cell embryo and then processed for in situ hybridization at stage 11. As shown in Figure 7D, DVR-4 eliminated the expression of Xnot, although formation of the dorsal lip was observed. Similar results were obtained when both cells of a two-cell embryo were injected (Table 1). These results demonstrate that the expression of genes within the gastrula organizing region can be disrupted by DVR4 , even though the timing of gastrulation, which begins in the same region, is unaffected.

The weak enhancement of Xnot transcription by FGF in the animal cap explants suggested that this factor might be important for the regulation of Xnot. This was tested by the use of a dominant-negative mutant of the Xenopus FGF receptor, which has been shown to disrupt FGF signaling in the Xenopus embryo (Amaya et al. 1991). Injection of RNA encoding the dominant-negative FGF receptor into the two dorsal cells of a four-cell em-

Table 1. Analysis of embryos injected with different RNAs

\begin{tabular}{|c|c|c|c|c|}
\hline & \multicolumn{4}{|c|}{ RNA injected } \\
\hline & Xwnt-8 & $\begin{array}{l}\text { DVR- } 4 \\
\text { ( } 2 \text { of } 2 \\
\text { cell) }\end{array}$ & $\begin{array}{l}\text { DVR-4 } \\
\text { ( } 2 \text { dorsal } \\
\text { cells of } 4)\end{array}$ & $\begin{array}{l}\text { FGF } \\
\text { (dominant } \\
\text { negative) }\end{array}$ \\
\hline Normal & 1 & 0 & 0 & 2 \\
\hline $\begin{array}{l}\text { Double } \\
\text { staining }\end{array}$ & 6 & - & - & - \\
\hline $\begin{array}{l}\text { Weak } \\
\text { staining }\end{array}$ & - & 4 & 1 & 0 \\
\hline No staining & - & 9 & 6 & 12 \\
\hline Embryos & 7 & 13 & 7 & 14 \\
\hline $\begin{array}{l}\text { Percent } \\
\text { affected }\end{array}$ & 86 & 100 & 100 & 86 \\
\hline
\end{tabular}

Embryos were injected with $X w n t-8$ in a single ventral cell of an 8- to 16-cell embryo, DVR-4 in either the two dorsal cells of a 4-cell embryo, or both cells of a 2-cell embryo, and the FGF dominant-negative receptor in the two dorsal cells of a 4-cell embryo. Embryos were fixed at stage 11 (Xwnt-8 and DVR-4) or stage 12 (FGF dominant negative) for in situ analysis with the $X$ not probe. Sibling embryos were left to develop to ensure that the reported phenotype was observed. bryo prevented the expression of Xnot within the organizing region (Fig. 7E; Table 1). Injection of dominantnegative FGF receptor RNA into the two ventral cells of a four-cell embryo had no effect (data not shown). These results demonstrate that FGF signaling is essential for the expression of Xnot within the gastrula organizing region.

\section{Discussion}

\section{Regulated expression of Xnot}

We have described the isolation of a novel homeo box gene, Xnot, which is expressed within the small group of cells referred to here as the gastrula organizing region. Although Xnot, like the organizer-specific homeo box gene goosecoid, is first transcribed at the start of zygotic transcription, it appears to be under a different type of regulatory control. From the first point at which it can be detected by in situ hybridization, goosecoid is transcribed only within the gastrula organizing region /Cho et al. 1991). Xnot, in contrast, is first expressed uniformly throughout the embryo, then expression progressively diminishes in the regions outside of the gastrula organizing region. The nonequatorial expression disappears first, leaving transcripts within the gastrula organizing region and a belt of Xnot expression around the equator, at or near the limit of involution. The equatorial expression vanishes soon after, leaving Xnot transcripts only within the organizing region. The selective disappearance of Xnot transcripts appears to be an active process, because each stage can be trapped by the addition of cycloheximide. Addition of cycloheximide at stage 9 prevented the abrupt decrease in Xnot expression that normally occurs at stage 10 and resulted in a high level of Xnot transcripts distributed throughout stage 12-equivalent embryos (Fig. 7A). Embryos receiving cycloheximide at stage 10 lost Xnot expression in the animal hemisphere but retained the equatorial transcripts in stage 12-equivalent embryos (Fig. 7B). These results suggest that the eventual localization of Xnot to the gastrula organizing region is the result of the progressive synthesis of a transcriptional repressor, first within the animal hemisphere and later in the equator outside of the gastrula organizing region. These results could equally be explained by the translation of a protein that leads to the progressive elimination of $X n o t$ transcripts from outside of the gastrula organizing region.

The pattern of Xnot expression is similar in some respects to that of Xenopus myoD, which also becomes restricted to a specific region after an initial phase of ubiquitous expression (Frank and Harland 1991; Harvey 1991; Rupp and Weintraub 1991; Harvey 1992). The localization of Xnot and myoD appears to work through different mechanisms, as myo $D$ is initially expressed at a very low level throughout the embryo but is then amplified 50- to 100-fold within the future somitic region. In contrast, Xnot is expressed initially at a high level but is then eliminated from all areas outside of the gastrula organizing region. We do not yet know whether the ini- 
tial activation of Xnot throughout the embryo is important for embryonic development, although the presence of Xnot transcripts on polysomes in pregastrula embryos indicates that the Xnot protein is synthesized before the start of gastrulation (G. von Dassow, J.E. Schmidt, and D. Kimelman, unpubl.).

\section{Regulation of Xnot expression by signaling factors}

Two parallel pathways appear to affect the localized expression of Xnot within the gastrula organizing region. Animal cap explant experiments demonstrate that both activin and FGF are able to enhance the expression of Xnot. Although FGF has a weaker effect on Xnot expression than activin, it was surprising that it had any effect, as the other organizer-specific genes are not regulated by FGF (Cho et al. 1991; Dirksen and Jamrich 1992; Ruiz i Altaba and Jessell 1992; Taira et al. 1992). FGF regulation of Xnot is likely to be important in vivo because injection of RNA encoding a dominant-negative mutant of the FGF receptor (Amaya et al. 1991) into the dorsal side of the embryo abolished the expression of Xnot. These results support the contention that FGF, together with a maternal Xwnt or noggin, is able to induce all mesoderm with the exception of the most anterior mesoderm (Christian et al. 1992; Kimelman and Maas 1992; for review, see Kimelman et al. 1992). In this view, the localized expression of Xnot in the organizing region is the result of high activity of noggin- or Xwnt-type signals at the dorsal midline of the equator which, together with FGF, induces the prenotochordal region (Kimelman et al. 1992). We suggest that the increase in Xnot expression caused by FGF in the animal cap assay is the result of low levels of Xwnt or noggin within the region of the animal hemisphere that the animal caps are derived from. Similarly, notochord is not induced in animal caps by exogenously added FGF unless the animal caps are isolated from embryos that had been injected with Xwnt-8 RNA (Christian et al. 1992). These results support the hypothesis that genes expressed within the organizing region can be regulated either by activin (goosecoid, Xlim, fork head, Xnot) or by FGF (Xnot), with the maternal $X w n t$ or noggin signal responsible for the localized expression of these genes on the dorsal midline.

Injection of DVR-4 RNA, which leads to the formation of ventralized embryos (Dale et al. 1992; Jones et al. 1992), was also able to block the expression of Xnot. Embryos injected with DVR-4 began gastrulation normally, demonstrating that the dorsal mesoderm in the organizer region is able to initiate gastrulation at the correct time. The elimination of Xnot transcription indicates that DVR-4 must act after the mechanism that establishes the timing of gastrulation but before at least some of the early organizer-specific transcription events occur. Because DVR-4 transcripts are found throughout the embryo (Dale et al. 1992; Jones et al. 1992), and yet Xnot is still expressed within the organizing region, DVR-4 may act as a generalized ventralizing factor that limits the extent of dorsal gene activation. In this view, competition between repressive signals such as DVR-4 and inductive signals such as activin or FGF might be responsible for creating the sharp boundaries of Xnot expression observed in the gastrula-stage embryo. Retinoic acid, which can alter the expression level of goosecoid, Xlim, and several Hox genes(Cho and De Robertis 1990; Cho et al. 1991; Taira et al. 1992), did not change the level of Xnot expression in the animal cap induction assay. Therefore, we suggest that retinoic acid does not have the same effect on all organizer-specific genes.

Our observations on the regulation of Xnot are presented in Figure 8. We suggest that Xnot is ubiquitously activated throughout the pregastrula embryo but is then progressively eliminated in all regions except those induced by activin or FGF together with noggin- or Xwnttype signals. The domain of Xnot expression may be limited through the action of DVR-4. We expect that Xnot in turn demarcates the prenotochordal region, perhaps by regulating the expression of brachyury (Smith et al. 1991) or the fork head genes (Dirksen and Jamrich 1992; Ruiz i Altaba and Jessell 1992), both of which become restricted to the notochord later than Xnot. Retinoic acid is suggested to function later than Xnot in regulating the expression of the Hox genes along the body axis.

\section{Multiple organizers}

Although expression of all five of the known organizerspecific genes appear by whole-mount in situ hybridiza-

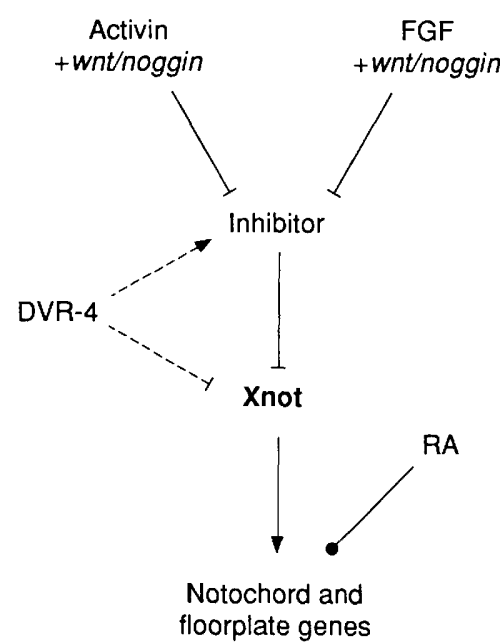

Figure 8. Summary of the regulation of Xnot expression. Both FGF and activin are able to induce the expression of Xnot, which is suggested to occur by the inhibition of a negative regulator of Xnot, which could either be a transcriptional repressor or a protein that leads to the degradation of Xnot RNA. DVR-4 can inhibit the expression of $X$ not and could work directly or by the activation of the inhibitor of Xnot. Retinoic acid does not regulate the levels of $X n o t$ transcription and, rather, is suggested to work at a later time in development or on a parallel pathway. Because Xnot is a likely transcription factor, its expression in the prenotochordal region is suggested to regulate other notochord- and floor plate-specific genes. 
tion to occupy nearly the same region of the embryo at the beginning of gastrulation, they may be expressed in distinct cells within this region. goosecoid and Xlim appear to be expressed within the cells of the organizing region that will become the anterior mesoderm /Cho et al. 1991; Taira et al. 1992). Although goosecoid is not expressed at the end of gastrulation when the anterior and posterior mesoderm are well separated, Xlim is clearly expressed in the prospective head mesoderm at this time (Taira et al. 1992). Xnot, in contrast, is expressed along the body axis at the end of gastrulation within the cells that will form the notochord and floor plate of the neural tube. Xnot is regulated differently than Xlim and goosecoid, because it is regulated by FGF, whereas these other two genes are not. Furthermore, injection of RNA encoding a dominant-negative version of the FGF receptor eliminates the expression of Xnot but not the expression of goosecoid (this paper; E. Amaya and M.W. Kirschner, pers. comm.). The different expression patterns and growth factor regulation of these organizer-specific genes may be related to the multiple organizer proposal of Gerhart et al. (1991). goosecoid and Xlim may be expressed within the head organizer, whereas Xnot (and perhaps fork head) might be components of the body axis organizer, which will give rise to the notochord.

This picture is most likely too simple because the Xenopus fork head genes appear to have properties that are intermediate between those of Xnot and goosecoid and Xlim. Like goosecoid and Xlim, the fork head genes are regulated by activin but not by FGF (Dirksen and Jamrich 1992; Ruiz i Altaba and Jessell 1992). Like Xnot, the expression of both fork head genes is restricted to the notochord and floor plate at the end of gastrulation (Dirksen and Jamrich 1992; Ruiz i Altaba and Jessell 1992). Earlier in gastrulation, however, Xnot and the fork head genes may be expressed within different regions; Xnot appears to be expressed at a greater distance from the blastopore lip and within a smaller arc around the marginal zone than the fork head genes (this paper; Dirksen and Jamrich 1992; Ruiz i Altaba and Jessell 1992). Hence the fork head genes might be initially expressed through the anterior and middle regions of the organizing region but might become restricted to the notochordal region through later regulation.

It will now be interesting to determine the role of the Xnot protein. Preliminary injection experiments did not reveal any axis-duplicating ability as has been reported with goosecoid (Cho et al. 1991). It may be necessary to coinject a combination of the other organizer-specific genes to observe axis duplication. In addition, injection of Xnot alone may produce subtle effects that could be revealed with a more detailed examination. Experiments of this type are in progress.

\section{Materials and methods}

Embryos and growth factors

Fertilized Xenopus embryos were prepared as described previously (Newport and Kirschner 1982). After the jelly coat was removed with $2 \%$ cysteine $(\mathrm{pH} 7.8)$, the eggs were washed in $0.1 \times \mathrm{MMR}\left(1 \times \mathrm{MMR}\right.$ is $0.1 \mathrm{M} \mathrm{NaCl}, 2 \mathrm{mM} \mathrm{KCl}, 1.0 \mathrm{mM} \mathrm{MgSO}_{4}$, $2.0 \mathrm{mM} \mathrm{CaCl}_{2}, 5.0 \mathrm{~mm}$ HEPES, and $0.1 \mathrm{mM}$ EDTA). Recombinant Xenopus bFGF (XbFGF) was prepared as described (Kimelman et al. 1988) and used at $250 \mathrm{ng} / \mathrm{ml}$. Activin A was a kind gift of Wylie Vale (Salk Institute, La Jolla, CA). It was used at 10 $\mathrm{ng} / \mathrm{ml}$ in the presence of $100 \mu \mathrm{g} / \mathrm{ml}$ of bovine serum albumin. Cycloheximide was used at $5 \mu \mathrm{g} / \mathrm{ml}$ in $0.1 \times \mathrm{MMR}$, a concentration that blocks cell division.

\section{Isolation of animal caps}

The upper portion of the animal hemisphere, corresponding to roughly one-fourth of the embryo, was manually separated at stage 8-9, with care taken to remove adhering vegetal cells, and cultured in $1 \times$ MMR. Where applicable, XbFGF or activin A was added to the buffer. The explants were harvested at stage 12-13 for RNA analysis.

\section{Isolation of Xenopus homeo box-containing sequences}

Oligo(dT)-primed cDNA was synthesized using mouse Moloney leukemia virus (M-MLV) polymerase (BRL) with RNA isolated from stage 12 embryos. The degenerate oligonucleotides used in the PCR encoded the first and third helices of the homeo box, GGGAGCTC(T/C)TNGA(A/G)AA(A/G)GA(A/G)TT(T/C)/T/ C)T and CGCGGATCC(T/G)XC(T/G)(A/G)TT/T/C)TG(A/G) AACCA, respectively. PCR conditions employed two cycles at $94^{\circ} \mathrm{C}$ for $1 \mathrm{~min}, 37^{\circ} \mathrm{C}$ for $3 \mathrm{mins}$, and $72^{\circ} \mathrm{C}$ for $1 \mathrm{~min}^{\circ}$ then 40 cycles at $94^{\circ} \mathrm{C}$ for $1 \mathrm{~min}, 60^{\circ} \mathrm{C}$ for 2 mins, and $72^{\circ} \mathrm{C}$ for $1 \mathrm{~min}$. After PCR, amplified fragments were isolated from polyacrylamide gels, digested with BamHI and SacI, which cleave at the ends of the PCR primers, and cloned into a Bluescript SK+ plasmid (Stratagene). Individual isolates were sequenced using the Sanger method (Sanger et al. 1977). The PCR fragments were used to isolate cDNAs from a stage 17 (neurula) phage library (Kintner and Melton 1987), which were inserted into the EcoRI site of a Bluescript SK + vector. The complete nucleotide sequence of the longest cDNA ( $\mathrm{p} X n$ not 1$)$ was determined and deposited in GenBank under accession number Z19577.

\section{RNA isolation and analysis}

RNA was prepared from whole embryos or animal cap explants by homogenization in a buffer containing proteinase $\mathrm{K}$ (Krieg and Melton 1984). The ethanol precipitate was dissolved in diethylpyrocarbonate-treated water and reprecipitated for at least $6 \mathrm{hr}$ with an equal volume of $8 \mathrm{M} \mathrm{LiCl}$ at $-20^{\circ} \mathrm{C}$. For Northern blot analysis, poly(A)-containing RNA from 50 embryos was isolated by oligo(dT)-cellulose chromatography, electrophoresed on a formaldehyde-agarose gel, transferred to Duralon (Stratagene), and immobilized by UV cross-linking. The filter was hybridized with an Xnot probe labeled with ${ }^{32} \mathrm{P}$ by random priming. RNase protection was performed with an antisense transcript from the middle of the Xnot cDNA (Fig. 1C) using a PvuII-PstI subclone inserted into Bluescript $\mathrm{KS}+$. This vector (pXnot 2) was linearized with HindIII and transcribed with T7 polymerase. As controls for RNA loading, antisense transcripts produced from the Xenopus EF1- $\alpha$ (Krieg et al. 1989) gene were synthesized with $\left[{ }^{32} \mathrm{P}\right] \mathrm{UTP}$ at a reduced specific activity (Sargent and Bennett 1990) and included in the hybridization reaction with the $\mathrm{pXnot} 2$ probe. RNase $\mathrm{A}$ and $\mathrm{T} 1$ were used at 40 $\mathrm{mg} / \mathrm{ml}$ and $2.0 \mathrm{mg} / \mathrm{ml}$, respectively, and the incubation was 1 $\mathrm{hr}$ at $30^{\circ} \mathrm{C}$. Quantitation of transcript levels was determined by densitometry using a Helena Laboratories densitometer. Xnot 
transcripts were normalized to the amount of $E F 1-\alpha$ in each sample.

\section{In situ hybridization and probe synthesis}

Whole-mount in situ hybridization was performed using digoxigenin-labeled RNA probes (Harland 1991), with the modification that levamisol was omitted from the alkaline phosphatase buffer. Antisense probes corresponding to the complete cDNA were synthesized from either HindIII-digested $\mathrm{pXnotl}$ or $\mathrm{p} X$ not 10 [the $\mathrm{pXnot} 1 \mathrm{cDNA}$ inserted in Bluescript KS +] DNA using T3 or T7 RNA polymerase, respectively. As a control, sense probes were synthesized from BamHI-digested $\mathrm{pXnotl}$ using $\mathrm{T} 7$ polymerase. After the alkaline phosphatase reaction, embryos were fixed and embedded in Paraplast Xtra. Embedded embryos were sectioned at $10 \mu \mathrm{m}$, stained with eosin, and mounted in Permount (Kelly et al. 1991). Whole-mount embryos and sections were photographed using Kodak Ektachrome 160T film.

\section{RNA synthesis and microinjection}

RNA was synthesized and microinjected following published procedures (Moon and Christian 1989). The following mRNAs were synthesized and injected: Xwnt-8 (Christian et al. 1991), DVR-4 (BMP-4; Dale et al. 1992), and XFD (dominant-negative FGF receptor; Amaya et al. 1991). Fifty picograms of Xwnt-8 mRNA was injected into a single ventral vegetal blastomere of 8- to 16-cell embryos. DVR-4 mRNA was injected into the two dorsal cells of four-cell embryos at 1-2 ng per blastomere, or the same amount was injected into both cells of two-cell embryos. Five hundred picograms of XFD mRNA was injected into both dorsal or both ventral blastomeres of four-cell embryos. Embryos were fixed for in situ hybridization at stage 11 or 12 . In all experiments, the dorsal side of four-cell embryos was identified by pigment and cell size differences between dorsal and ventral blastomeres at this stage (Nieuwkoop and Faber 1956).

\section{Acknowledgments}

We are very grateful to Enrique Amaya and Marc Kirschner for supplying the dominant-negative FGF receptor, detailed information on its use, and for communicating results before publication. Jim Smith kindly supplied the DVR-4 (BMP-4) clone, and Jan Christian, the Xwnt-8 clone. We thank Enrique Amaya, Randall Moon, and Tim Schuh for their detailed and insightful comments on this manuscript, and Rob Cornell, Jennifer Northrop, and members of the laboratory for their respective contributions. This work was supported by grants from the $\mathrm{Na}$ tional Institutes of Health, Searle Scholars Foundation, and the March of Dimes. J.S. is a recipient of a Howard Hughes predoctoral fellowship.

The publication costs of this article were defrayed in part by payment of page charges. This article must therefore be hereby marked "advertisement" in accordance with 18 USC section 1734 solely to indicate this fact.

\section{References}

Amaya, E., T.J. Musci, and M.W. Kirschner. 1991. Expression of a dominant negative mutant of the FGF receptor disrupts mesoderm formation in Xenopus embryos. Cell 66: 257270.

Cho, K.W.Y. and E.M. De Robertis. 1990. Differential activation of Xenopus homeo box genes by mesoderm-inducing growth factors and retinoic acid. Genes \& Dev. 4: 1910-1916.

Cho, K.W.Y., B. Blumberg, H. Steinbesser, and E.M. De Robertis. 1991. Molecular nature of Spemann's organizer: The role of the Xenopus homeobox gene goosecoid. Cell 67: 11111120.

Christian, J.L., J.A. McMahon, A.P. McMahon, and R.T. Moon. 1991. Xwnt-8, a Xenopus Wnt-1/int-1-related gene responsive to mesoderm inducing factors, may play a role in ventral mesodermal patterning during embryogenesis. Development 111: 1045-1056.

Christian, J.L., D.J. Olson, and R.T. Moon. 1992. Xwnt-8 modifies the character of mesoderm induced by bFGF in isolated Xenopus ectoderm. EMBO I. 11: 33-41.

Dale, L., G. Howes, B.M.J. Price, and J.C. Smith. 1992. Bone morphogenetic protein 4: A ventralizing factor in early $\mathrm{Xe}$ nopus development. Development 115: 573-585.

Dirksen, M.L. and M. Jamrich. 1992. A novel, activin-inducible, blastopore lip-specific gene of Xenopus laevis contains a fork head DNA-binding domain. Genes \& Dev. 6: 599-608.

Frank, D. and R.M. Harland. 1991. Transient expression of $\mathrm{XMyoD}$ in non-somite mesoderm of Xenopus gastrulae. Development 113: 1387-1393.

- 1992. Localized expression of Xenopus POU gene depends on cell-autonomous transcriptional activation and induction-dependent inactivation. Development 115: 439448.

Gerhart, J.C., R. Stewart, and T. Doniach. 1991. Organizing the Xenopus organizer. In Gastrulation: Movements, patterns, and molecules (ed. R. Keller, W. Clark Jr. and F. Griffin), pp. 57-77. Plenum Press, New York.

Harland, R.M. 1991. In situ hybridization: An improved whole mount method for Xenopus embryos. Methods Cell Biol. 36: 685-695.

Harvey, R.P. 1991. Widespread expression of MyoD genes in Xenopus embryos is amplified in presumptive muscle as a delayed response to mesoderm induction. Proc. Natl. Acad. Sci. 88: 9198-9202.

1992. MyoD protein expression in Xenopus embryos closely follows a mesoderm induction-dependent amplification of MyoD transcription and is synchronous across the future somite axis. Mech. Dev. 37: 141-149.

Jones, C.M., K.M. Lyons, P.M. Lapan, C.V.E. Wright, and B.L.M. Hogan. 1992. DVR-4 (bone morphogenetic protein-4) as a posterior ventralizing factor in Xenopus mesoderm induction. Development 115: 639-647.

Kaneda, T. and T. Hama. 1979. Studies on the formation and state of determination of the trunk organizer in the newt $C$. pyrrhogaster. Wilhelm Roux's Arch. 187: 25-34.

Keller, R.E. 1976. Vital dye mapping of the gastrula and neurula of Xenopus laevis. Dev. Biol. 51: 118-137.

Kelly, G.M., D.W. Eib, and R.T. Moon. 1991. Histological preparations of Xenopus laevis oocytes and embryos. Methods Cell Biol. 36: 389-419.

Kimelman, D. and M. Kirschner. 1987. Synergistic induction of mesoderm by FGF and TGF- $\beta$ and the identification of an mRNA coding for FGF in the early Xenopus embryo. Cell 51: 869-877.

Kimelman, D. and A. Maas. 1992. Induction of dorsal and ventral mesoderm by ectopically expressed Xenopus basic fibroblast growth factor. Development 114: 261-269.

Kimelman, D., J.A. Abraham, T. Haaparanta, T.M. Palisi, and M. Kirschner. 1988. The presence of FGF in the frog egg: Its role as a natural mesoderm inducer. Science 242: 10531056.

Kimelman, D., J.L. Christian, and R.T. Moon. 1992. Synergistic principles of development: Overlapping patterning systems 
in Xenopus mesoderm induction. Development 116: 1-9.

Kintner, C.R. and D.A. Melton. 1987. Expression of Xenopus N-CAM RNA in ectoderm is an early response to neural induction. Development 99: 311.

Kozak, M. 1987. An analysis of 5 '-noncoding sequences from 699 vertebrate messenger RNAs. Nucleic Acids Res. 15: $8125-8148$.

Krieg, P. and D. Melton. 1984. Functional messenger RNAs are produced by SP6 in vitro transcription of cloned DNAs. $\mathrm{Nu}$ cleic Acids Res. 12: 7057-7070.

Krieg, P.A., S. Varnum, M.W. Wormington, and D.A. Melton. 1989. The mRNA encoding elongation factor $1-\alpha(E F-1 \alpha)$ is a major transcript of the midblastula transition. Dev. Biol. 133: 93-100.

Laughon, A. 1991. DNA binding specificity of homeodomains. Biochemistry 30: 11367-11372.

Moon, R.T. and J.L. Christian. 1989. Microinjection and expression of synthetic mRNAs in Xenopus embryos. Technique 1: 76-89.

Newport, J. and M.W. Kirschner. 1982. A major developmental transition in early Xenopus embryos. I. Characterization and timing of cellular changes at the midblastula stage. Cell 30: 675-686.

Nieuwkoop, P.D. and J. Faber. 1956. Normal table of Xenopus laevis. North-Holland Publishing Company, Amsterdam, The Netherlands.

Ptashne, M. 1988. How eukaryotic transciptional activators work. Nature 335: 683-689.

Ruiz i Altaba, A. and T.M. Jessell. 1992. Pintallavis, a gene expressed in the organizer and midline cells of frog embryos: Involvement in development of the neural axis. Development 116: 81-93.

Rupp, R.A. and H. Weintraub. 1991. Ubiquitous MyoD transcription at the midblastula transition precedes inductiondependent MyoD expression in presumptive mesoderm of $\mathrm{X}$. laevis. Cell 65: 927-937.

Sanger, F., S. Nicklen, and A.R. Coulson. 1977. DNA sequencing with chain-terminating inhibitors. Proc. Natl. Acad. Sci. 74: 5436-5467.

Sargent, M.G. and M.F. Bennett. 1990. Identification in Xenopus of a structural homologue of the Drosophila gene Snail. Development 109: 967-973.

Shiurba, R.A., N. Jing, T. Sakakura, and S.F. Godsave. 1991. Nuclear translocation of fibroblast growth factor during $\mathrm{Xe}$ nopus mesoderm induction. Development 113: 487-493.

Slack, J.M.W. and H.V. Isaacs. 1989. Presence of basic fibroblast growth factor in the early Xenopus embryo. Development 105: $147-153$.

Smith, J.C. 1987. A mesoderm-inducing factor is produced by a Xenopus cell line. Development 99: 3-14.

Smith, J.C., B.M.J. Price, K. Van Nimmen, and D. Huylebroeck. 1990. Identification of a potent Xenopus mesoderm-inducing factor as a homologue of activin A. Nature 345: 729-731.

Smith, J.C., B.M.J. Price, J.B.A. Green, D. Weigel, and B.G. Herrmann. 1991. Expression of a Xenopus homolog of brachyury $\langle\mathrm{T}\rangle$ is an immediate-early response to mesoderm induction. Cell 67: 79-87.

Smith, W.C. and R.M. Harland. 1991. Injected Xwnt-8 acts early in Xenopus embryos to promote formation of a vegetal dorsalizing center. Cell 67: 753-766.

. 1992. Expression cloning of noggin, a new dorsalizing factor localized in the Spemann organizer in Xenopus embryos. Cell 70: $829-840$.

Sokol, S., J.L. Christian, R.T. Moon, and D.A. Melton. 1991. Injected wnt RNA induces a complete body axis in Xenopus embryos. Cell 67: 741-752.
Spemann, H. 1938. Embryonic development and induction. Yale University Press, New Haven, CT.

Spemann, H. and H. Mangold. 1924. Uber induction von embryonalagen durch implantation artfremder organis atoren. Wilhelm Roux's Arch. Entwicklungsmecher Org. 100: 599638.

Taira, M., M. Jamrich, P.J. Good, and I.B. Dawid. 1992. The LIM domain-containing homeo box gene Xlim-1 is expressed specifically in the organizer region of Xenopus gastrula embryos. Genes \& Dev. 6: 356-366.

Thomsen, G., T. Woolf, M. Whitman, S. Sokol, J. Vaughan, W. Vale, and D.A. Melton. 1990. Activins are expressed in Xenopus embryogenesis and can induce axial mesoderm and anterior structures. Cell 63: 485-493. 


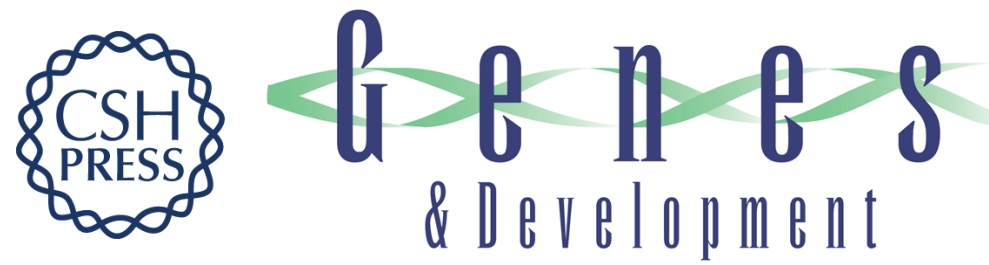

\section{Induction of the Xenopus organizer: expression and regulation of Xnot, a novel FGF and activin-regulated homeo box gene.}

G von Dassow, J E Schmidt and D Kimelman

Genes Dev. 1993, 7:

Access the most recent version at doi:10.1101/gad.7.3.355

References This article cites 43 articles, 18 of which can be accessed free at:

http://genesdev.cshlp.org/content/7/3/355.full.html\#ref-list-1

License

Email Alerting

Service

Receive free email alerts when new articles cite this article - sign up in the box at the top right corner of the article or click here.

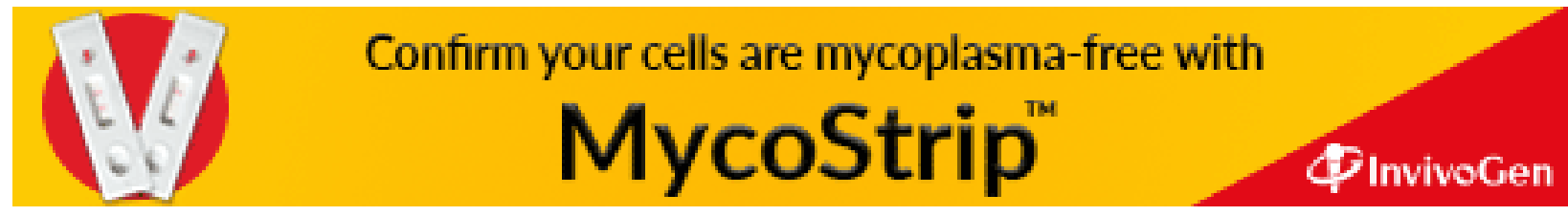

